Article

\title{
The Role of VEGFA, COX2, HUR and CUGBP2 in Predicting the Response to Neoadjuvant Therapy in Rectal Cancer Patients
}

\author{
Henrikas Pauzas ${ }^{1, \dagger}{ }^{\dagger}$ Ugne Gyvyte ${ }^{2, \dagger}{ }^{,}$Tadas Latkauskas ${ }^{1}$, Laura Kairevice ${ }^{3}$, Paulius Lizdenis ${ }^{1}$, \\ Saulius Svagzdys ${ }^{1}$, Erika Birgiolaite ${ }^{1}$, Irma Kuliaviene ${ }^{4}$, Juozas Kupcinskas ${ }^{2,4, \pm(1)}$ and \\ Algimantas Tamelis $1, *, \ddagger$ \\ 1 Department of Surgery, Academy of Medicine, Lithuanian University of Health Sciences, \\ LT-50161 Kaunas, Lithuania; henrikas.pauzas@lsmuni.lt (H.P.); tadas.latkauskas@lsmuni.lt (T.L.); \\ paulius.lizdenis@lsmuni.lt (P.L.); saulius.svagzdys@lsmuni.lt (S.S.); erikabirgiolaite@yahoo.com (E.B.) \\ 2 Institute for Digestive Research, Academy of Medicine, Lithuanian University of Health Sciences, \\ LT-50161 Kaunas, Lithuania; ugne.gyvyte@lsmuni.lt (U.G.); juozas.kupcinskas@lsmuni.lt (J.K.) \\ 3 Department of Oncology and Hematology, Academy of Medicine, Lithuanian University of Health Sciences, \\ LT-50161 Kaunas, Lithuania; laura.kairevice@lsmuni.lt \\ 4 Department of Gastroenterology, Academy of Medicine, Lithuanian University of Health Sciences, \\ LT-50161 Kaunas, Lithuania; irma.kuliaviene@lsmuni.lt \\ * Correspondence: algimantas.tamelis@1smuni.lt \\ + Equally contributed to the study. \\ $\ddagger$ Equally contributed to the study.
}

Received: 31 March 2020; Accepted: 20 April 2020; Published: 22 April 2020

Abstract: Background and objectives: The effectiveness of neoadjuvant therapy, which is commonly used for stage II-III rectal cancer (RC) treatment, is limited. Genes associated with the pathogenesis of $\mathrm{RC}$ could determine response to this treatment. Therefore, the aim of this study was to investigate the potential predictive value of VEGFA, COX2, HUR and CUGBP2 genes and the associations between post-treatment changes in gene expression and the efficacy of neoadjuvant therapy. Materials and Methods: Biopsies from RC and healthy rectal tissue of $28 \mathrm{RC}$ patients were collected before neoadjuvant therapy and 6-8 weeks after neoadjuvant therapy. The expression levels of VEGFA, COX2, HUR, CUGBP2 genes were evaluated using a quantitative real-time polymerase chain reaction. Results: The results reveal a significantly higher expression of VEGFA, COX2 and HUR mRNA in RC tissue compared to healthy rectal tissue $(p<0.05)$, and elevated VEGFA gene expression in pre-treatment tissues was associated with a better response to neoadjuvant therapy based on T-stage downstaging $(p<0.05)$. The expression of VEGFA, HUR and CUGBP2 genes significantly decreased after neoadjuvant therapy $(p<0.05)$. Responders to treatment demonstrated a significantly stronger decrease of VEGFA and COX2 expression after neoadjuvant therapy than non-responders $(p<0.05)$. Conclusions: The findings of this study suggest that the pre-treatment VEGFA gene expression might have predictive value for the response to neoadjuvant therapy, while the post-treatment decrease in VEGFA and COX2 gene expression could indicate the effectiveness of neoadjuvant therapy in RC patients.

Keywords: rectal cancer; neoadjuvant therapy; VEGFA; COX2; HUR; CUGBP2

\section{Introduction}

Colorectal cancer (CRC) screening programs have huge potential in reducing the burden of $\mathrm{CRC}$ in countries that have well-running screening platforms [1]. Nevertheless, current estimates of 
the worldwide incidence and mortality from rectal cancer $(\mathrm{RC})$ obligate us to look for more precise diagnostics and better treatment options [2]. Neoadjuvant therapy with delayed surgery is the most common regimen reducing the local recurrence rate for patients with resectable rectal cancer. Tumor downstaging and the pathological complete response has been associated with the effectiveness of neoadjuvant therapy and could be prognostic factors to predict individual clinical outcome $[3,4]$. However, the effectiveness of neoadjuvant therapy is limited, and the downstaging rate ranges between $40 \%$ and $60 \%[3,5-8]$.

The pathogenesis of CRC is complex and may involve multiple genetic [9-12], epigenetic [13,14] and environmental factors [15] that may contribute to tumor development. Recent studies suggested that genes associated with the pathogenesis of $\mathrm{RC}$, such as vascular endothelial growth factor $\mathrm{A}$ (VEGFA), cyclooxygenase 2 (COX2), human antigen R (HUR) and CUG triplet repeat RNA binding protein (CUGBP2), and their products could predict the response to neoadjuvant therapy and, therefore, improve clinical care by selecting an optimal treatment for RC patients, or be prognostic factors in colorectal cancer (CRC) [16-33]. The overexpression of COX2 has been observed in multiple cancers, including $C R C$, and can induce the expression of $V E G F$, leading to increased angiogenesis and tumor progression $[34,35]$, while AU-rich element-binding (ARE) proteins HUR and CUGBP2 have been shown to stabilize and modulate COX2 expression [36].

In this study, we aimed to evaluate the associations between expression levels of VEGFA, COX2, HUR and CUGBP2 genes and the response to neoadjuvant therapy in RC patients.

\section{Materials and Methods}

\subsection{Study Population and Samples}

Research of VEGFA, COX2, HUR and CUGBP2 gene expression in rectal cancer was the experimental part of a prospective randomized trial "Preoperative conventional chemoradiotherapy versus short-course radiotherapy with delayed surgery for rectal cancer" [37]. The study was approved by the Kaunas Regional Committee of Ethics of Biomedical Research (Protocol No. P2-137/2006, 8 December 2011). All patients have signed an informed consent form to participate in the study. The inclusion, exclusion criteria and initial results of the aforementioned prospective trial have been previously reported [38,39]. In short, patients under 80 years old with histologically confirmed stage II and III rectal cancer, located less than $15 \mathrm{~cm}$ from the anal verge, with no other cancer during the previous five years and normal cardiovascular, pulmonary, hepatic and renal functions, were included in the study. Initially, it was planned to collect RC and healthy rectal tissue samples of $50 \mathrm{RC}$ patients for the gene expression analysis during the years 2011-2013; however, due to the progression of the disease, the cancellation of the surgery, an insufficient amount of tissue sample or an insufficient amount and poor quality of RNA, and the inability to take the samples repeatedly, $27 \mathrm{RC}$ patients were finally investigated in the study. The characteristics of patients included in the study are provided in Table 1. The downstaging of the tumor was evaluated, comparing changes in the clinical and pathological stage. Clinical $\mathrm{T}$ and $\mathrm{N}$ stages were assessed using endorectal ultrasound and magnetic resonance imaging before the neoadjuvant therapy and re-evaluated after radiotherapy, before the surgery. The post-surgical pathological stage was determined based on the pathologist's conclusions. The pathological "T/N-stage downstaging" (comparing post-surgical ypT/ypN to the pre-treatment $\mathrm{CT} / \mathrm{cN}$ ) has been considered when clinical stage cII-III has become a pathological p0-I stage (according to the American Joint Committee on Cancer (AJCC) staging system) after neoadjuvant therapy. "T-stage downstaging" has been considered when the pathological T-stage decreased after neoadjuvant therapy comparing to the clinical T-stage (comparing post-treatment ypT to the pre-treatment $\mathrm{cT}$ ). A summary of patient distribution according to AJCC and TNM staging systems before and after neoadjuvant therapy is provided in the Table S1 of the Supplementary Materials.

Tissue samples were taken during the endoscopic examination before neoadjuvant therapy $(n=27)$ and repeatedly taken $6-8$ weeks after neoadjuvant therapy (conventional chemoradiotherapy 
(CRT; 50 Gy in total administered during a period of 5 weeks, 2 Gy per fraction and two cycles of 5-FU/Leucovorin, $400 \mathrm{mg} / \mathrm{m}^{2}$ of 5-fluorouracil i/v in combination with leucovorin $20 \mathrm{mg} / \mathrm{m}^{2} \mathrm{i} / \mathrm{v}$ for 1-4 days on the first and on the fifth week) or short-term radiotherapy (RT; 5 fractions of radiotherapy, 5 Gy per fraction, administered each day for 5 days, a dose of 25 Gy in total)) on surgery day after tumor removal $(n=12)$. To stabilize RNA, biopsies were treated with "RNA later ${ }^{\circledR}$ Solution" and frozen to $-80^{\circ} \mathrm{C}$ after $24 \mathrm{~h}$.

Table 1. Summary of clinical characteristics of rectal cancer (RC) patients. RT-radiotherapy, CRT—chemoradiotherapy, SD—standard deviation.

\begin{tabular}{|c|c|c|}
\hline Number & 27 & \\
\hline Age (Mean \pm SD) & $66.5 \pm 8.75$ & \\
\hline \multicolumn{3}{|l|}{ Gender, $N(\%)$} \\
\hline Male & $18(67)$ & \\
\hline Female & $9(33)$ & \\
\hline Downstaging, $N(\%)$ & Based on T-stage $(c T \rightarrow y p T)$ & $\begin{array}{c}\text { Based on T/N stages } \\
(c T / c N \rightarrow y p T / y p N ; A J C C \text { staging } c I I-I I I \rightarrow y p 0-I)\end{array}$ \\
\hline Downstaged & $9(33)$ & $7(26)$ \\
\hline Non-downstaged & $14(52)$ & $16(59)$ \\
\hline No data & $4(15)$ & $4(15)$ \\
\hline \multicolumn{3}{|c|}{ Neoadjuvant therapy, $N(\%)$} \\
\hline RT & $11(41)$ & \\
\hline CRT & $16(59)$ & \\
\hline
\end{tabular}

\subsection{RNA Isolation}

Up to $50 \mathrm{mg}$ of tissue was used for RNA isolation using a "Direct-zol ${ }^{\mathrm{TM}}$ RNA MiniPrep" (Zymo Research, Irvine, CA, USA) Kit. RNA concentration and purity were evaluated by spectrophotometer NanoDrop 2000 (>150 ng/ $\mu$ L RNA concentration and A260/A280 purity value 1.8-2.0 were required for further research). Extracted RNA was further stored at $-80{ }^{\circ} \mathrm{C}$.

\subsection{Reverse Transcription and $q P C R$ Analysis}

Isolated RNA was used for complementary DNA (cDNA) synthesis by using a SuperScript ${ }^{\circledR}$ VILO $^{\mathrm{TM}}$ cDNA Synthesis Kit (Invitrogen ${ }^{\mathrm{TM}}$, Carlsbad, CA, USA) according to the manufacturer's protocol. In order to detect the expression of VEGFA, COX2, HUR and CUGBP2 genes, the resulting cDNA was subjected to the quantitative real-time PCR (qPCR) using primers and probes from TaqMan ${ }^{\circledR}$ Gene Expression Assays (Hs0090005_m1 VEGFA, Hs00153733_m1 PTGS (COX2), Hs00171309_m1 ELAVL1 (HUR), Hs00272516_m1 CELF2 (CUGBP2)) together with TaqMan ${ }^{\circledR}$ Universal PCR Mastermix II (no UNG) on the 7500 Fast Real-Time PCR System (Applied Biosystems, Foster City, CA, USA), according to the manufacturer's recommendations. The expression data were normalized to the expression levels of $A C T B$ reference gene.

\subsection{Statistical Analysis}

qPCR data were analyzed using the comparative $C_{T}$ method. Differences in gene expression between investigated groups were evaluated using a Wilcoxon signed-rank test (for dependent samples, including RC vs. healthy tissue, before vs. after therapy) or a Wilcoxon rank-sum test (for independent samples, including downstaging vs. non-downstaging groups) for non-parametric data. Pearson's correlation coefficients were calculated to determine the correlations between gene expression levels. Differences between the investigated groups were considered significant when $p<0.05$. All statistical analyses were performed using the statistical computing environment $\mathrm{R}$ (version 3.5.2). 


\section{Results}

\subsection{Expression of VEGFA, COX2 and HUR is Altered in Rectal Cancer Tissue}

Analysis of VEGFA, COX2, HUR and CUGBP2 gene expression in the samples taken before neoadjuvant therapy $(n=27)$ revealed a significant upregulation of $V E G F A, C O X 2$, and HUR mRNA in $\mathrm{RC}$ tissue compared to healthy rectal mucosa $\left(2.4\right.$-fold, $p=9.2 \times 10^{-4}$; 5-fold, $p=7.3 \times 10^{-5} ; 1.4$-fold, $p=0.02$, respectively), while no difference was observed in the expression levels of CUGBP2 mRNA $(p>0.05)$ (Figure 1). In addition, high positive correlations were observed between the expression levels of VEGFA and COX2 $\left(\mathrm{R}=0.74, p=2.2 \times 10^{-10}\right)$ or HUR $\left(\mathrm{R}=0.71, p=2.2 \times 10^{-9}\right)$, as well as between COX2 and HUR $\left(\mathrm{R}=0.7, p=3.8 \times 10^{-9}\right)$ genes (Figure 2$)$.

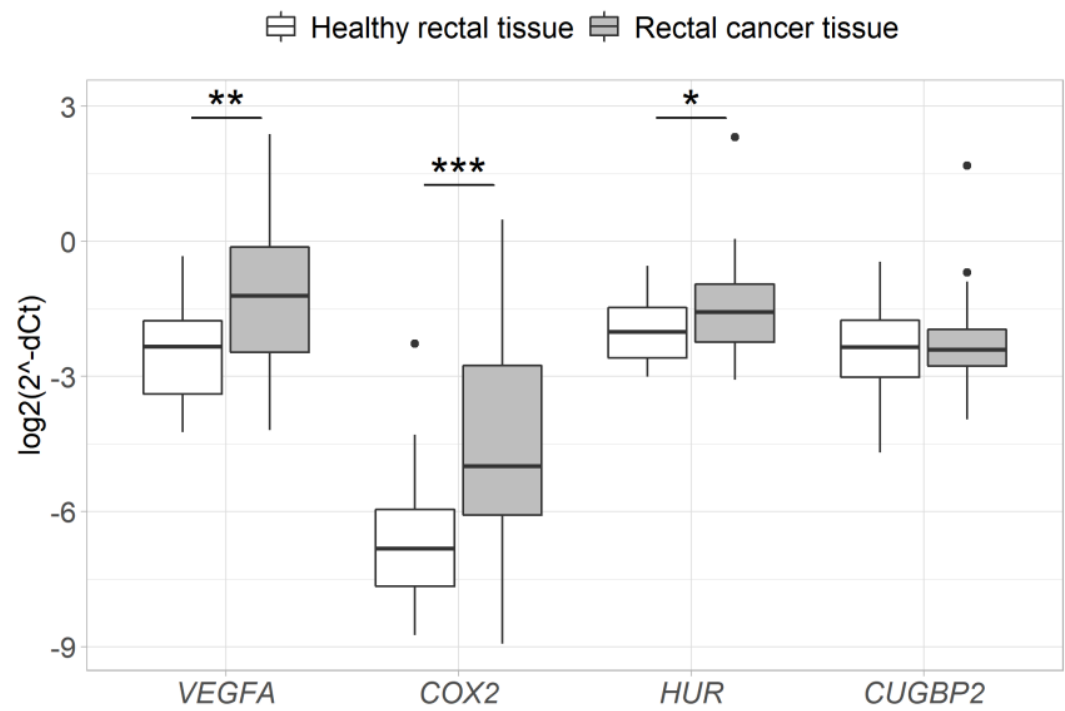

Figure 1. Expression of VEGFA, COX2, HUR and CUGBP2 genes in RC vs. healthy rectal tissue. $*-p<0.05,{ }^{* *}-p<0.005,{ }^{* * *}-p<0.0005$. Gene expression was normalized to the expression levels of the $A C T B$ reference gene.
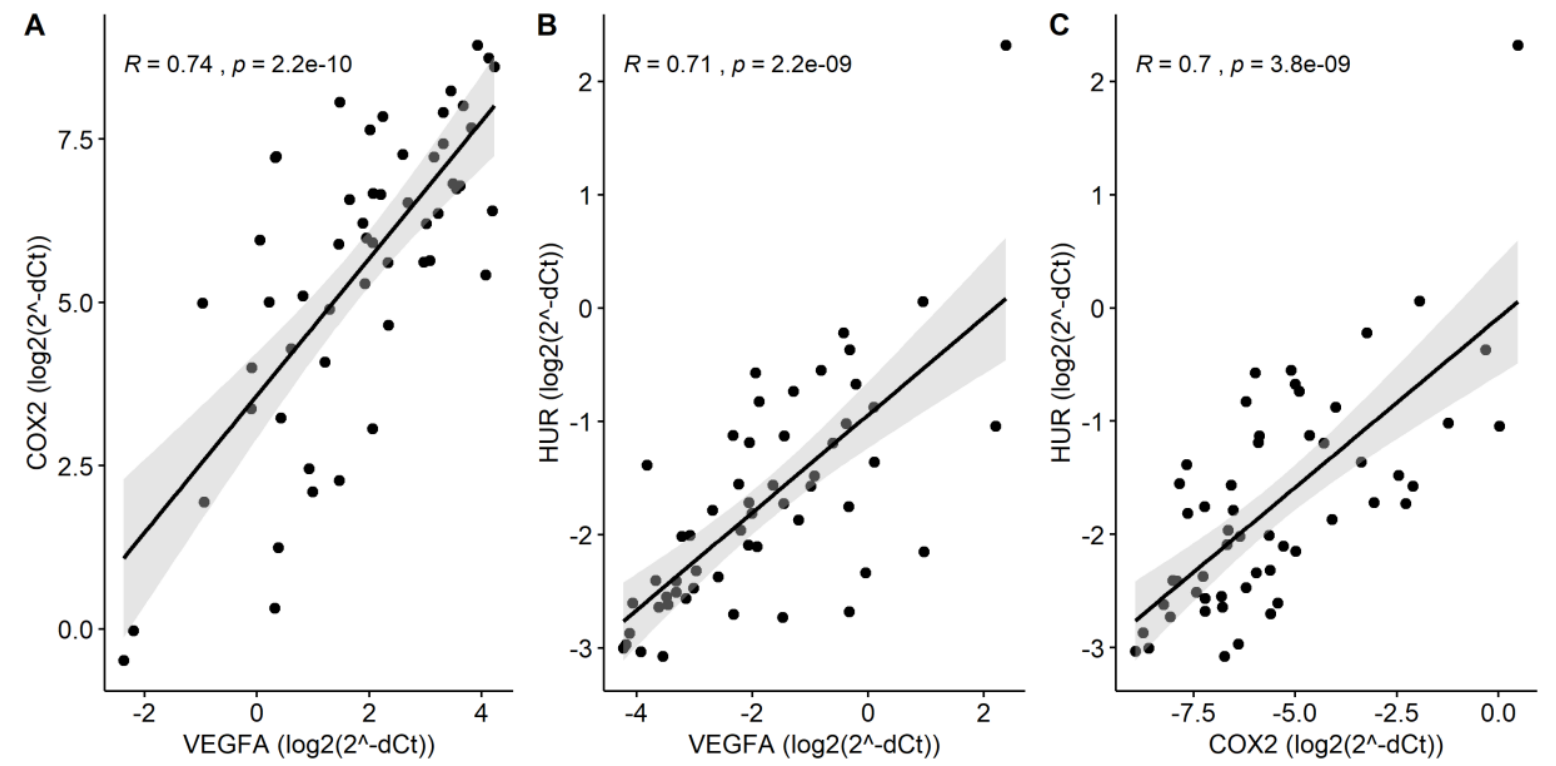

Figure 2. A significant correlation between the expression levels of RC-deregulated genes. A high positive correlation between the expression of (A) COX2 and VEGFA; (B) HUR and VEGFA; (C) HUR and COX2 genes. R-Pearson's correlation coefficient; correlation is significant when $p<0.05$. 


\subsection{Pre-Treatment Expression of VEGFA Is Associated with a Response to Neoadjuvant Therapy}

In order to evaluate the association between the pre-treatment expression and response to neoadjuvant therapy, differences of gene expression between the groups of responders and non-responders (based on pathological T/N-stage and T-stage downstaging) were assessed. The results reveal that tumors in a T-stage downstaging group had a significantly higher expression of the VEGFA gene before the neoadjuvant therapy (2.9-fold, $p=0.028$ ) (Figure 3), while no difference in gene expression was observed between pathological T/N-stage downstaging and non-downstaging groups (Figure 4).

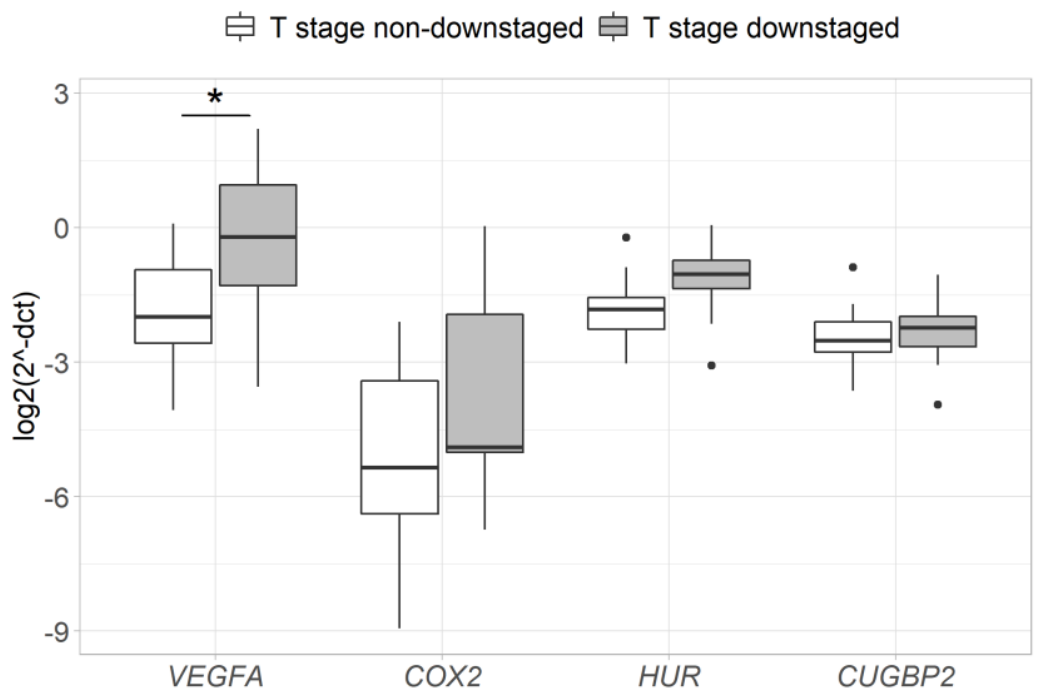

Figure 3. Pre-treatment levels of VEGFA, COX2, HUR and CUGBP2 gene expression compared between the groups of RC patients with and without T-stage downstaging (following neoadjuvant therapy). * $-p<0.05$. Gene expression was normalized to the expression levels of the ACTB reference gene.

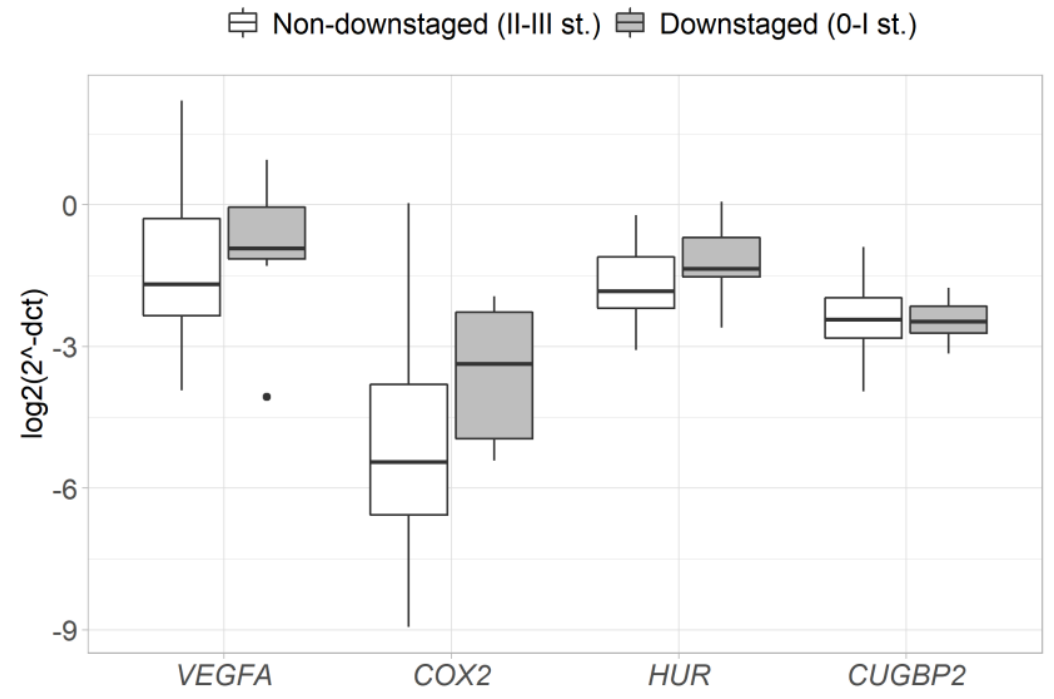

Figure 4. Pre-treatment levels of VEGFA, COX2, HUR and CUGBP2 gene expression compared between the groups of RC patients with and without pathological T/N-stage downstaging (cII-III to ypI-II) (following neoadjuvant therapy). Gene expression was normalized to the expression levels of the ACTB reference gene. 
3.3. Changes in VEGFA and COX2 Expression during Neoadjuvant Therapy Is Associated with a Response to Treatment

Changes in the expression of VEGFA, COX2, HUR and CUGBP2 genes after neoadjuvant therapy were successfully evaluated in the group of 12 patients. Due to the small sample size, CRT- and RT- treated patients were analyzed as a single neoadjuvant therapy group. Analysis revealed a significant decrease in VEGFA, HUR and CUGBP2 gene expression after neoadjuvant therapy compared to the expression levels before the treatment (2.6-fold, $p=0.034 ; 2.8$-fold, $p=0.002 ; 1.7$-fold, $p=0.034$, respectively). No significant changes in the expression of the COX2 gene were observed after neoadjuvant therapy $(p>0.05)$ (Figure 5). Furthermore, the group of T-stage responders demonstrated a more prominent VEGFA and COX2 expression decrease after neoadjuvant therapy than the group of T-stage non-responders $(p<0.05)$ (Figure 6).

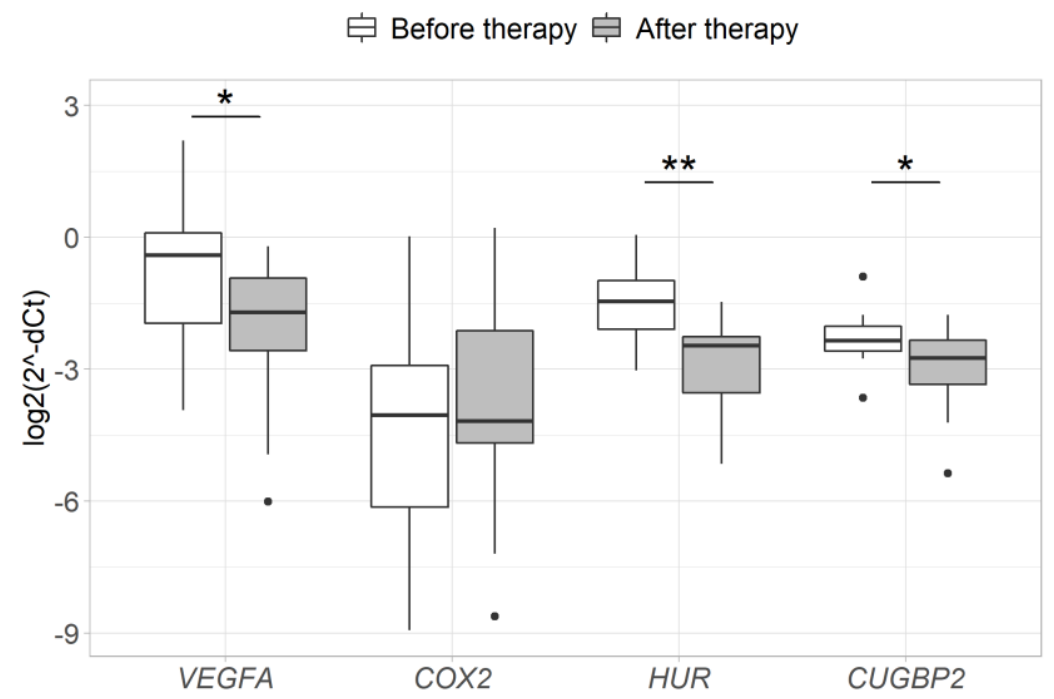

Figure 5. Expression of VEGFA, COX2, HUR and CUGBP2 genes in RC tissue before vs. after neoadjuvant therapy. ${ }^{*}-p<0.05,{ }^{* *}-p<0.005,{ }^{* * *}-p<0.0005$. Gene expression was normalized to the expression levels of the ACTB reference gene.

追 T stage non-downstaged 追 T stage downstaged

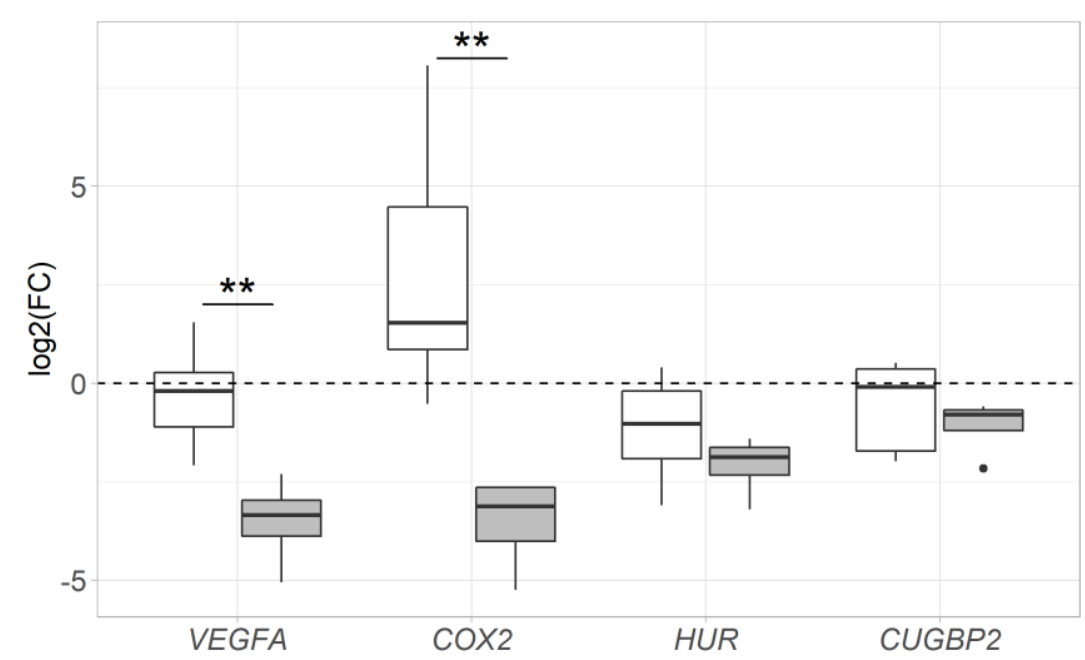

Figure 6. Differences in fold changes of gene expression after neoadjuvant therapy compared between the groups of responders and non-responders (based on T-stage downstaging). 


\section{Discussion}

In the present study, we analyzed the expression of VEGFA, COX2, HUR and CUGBP2 genes and their alterations in response to neoadjuvant therapy in the tissues of $R C$ and healthy rectal mucosa. We further evaluated the associations between gene expression and patient response to neoadjuvant treatment. The major findings of our study indicate the possible predictive value of pre-treatment VEGFA mRNA expression for the response to neoadjuvant therapy, while post-treatment changes in the expression of VEGFA and COX2 mRNA may have potential, indicating the effectiveness of neoadjuvant therapy in RC patients.

Higher levels of VEGFA, COX2 and HUR mRNA were detected in RC tissue compared to the healthy rectal mucosa. VEGFA gene encodes a well-studied pro-angiogenic factor that induces endothelial cell proliferation, migration, survival, and therefore contributes to tumor angiogenesis [40]. COX2 is an enzyme induced by growth factors, inflammatory mediators, and tumor promoters [34]. There is sufficient data confirming positive correlations between the amount of COX2 protein in cancerous tissue and staging, metastasis and survival rate in a variety of tumors, including CRC [34,41-43]. It has been shown that the overexpression of COX2 and its enzymatic product prostaglandin E2 (PGE2) are related to the increased amount of VEGFA, which promotes the formation of various small vessels in tumors [34,44]. Although there are a lot of data on COX2 and VEGFA protein expression in the tissues of CRC, there are only a few publications on their mRNA expression. Our results are consistent with the prior data found in the literature describing the upregulation of COX2 and VEGFA genes in the cancerous tissues of colon and rectum compared to healthy tissues $[17,22,23,45,46]$ and confirm that changes in the expression of these genes happen already at the mRNA level during pathological processes. Moreover, a positive correlation between the expression levels of COX2 and VEGFA mRNA was found, supporting the previously described interaction between COX2 and VEGFA $[34,47]$.

The products of HUR and CUGBP2 genes take part in the regulation of VEGFA and COX2 translation to protein, selectively attaching to ARE sequences in their mRNA [26,36,48]. However, the mechanisms of gene expression regulation by these RNA-binding proteins are not entirely clear. It has been proven that HUR protein is overexpressed in CRC, is associated with the activation of COX2 and $V E G F A$ gene expression in tumor endothelial cells and, therefore, is an important factor activating angiogenesis in tumor cells and plays an important role in cancer development and progression by targeting the mRNAs of proto-oncogenes, cytokines, growth and invasion factors [23-26,48,49]. In this study, we found a significant increase in HUR mRNA expression in RC tissue compared to the surrounding healthy tissue and a high positive correlation between expression levels of HUR and COX2 or VEGFA, which confirmed the results of a study performed by Young et al. [23]. Contrarily, CUGBP2 has been shown to be downregulated in colon cancer, inhibit COX2 mRNA translation to protein and prevent cancer development [50,51]. However, no differences were observed in CUGBP2 gene expression comparing healthy and cancerous rectal tissues in this study. Few studies, evaluating changes in CUGBP2 gene expression, have been reported, suggesting that the CUGBP2 gene expression changes only when affected by radiation [29].

It has been previously shown that VEGFA, COX2 and HUR genes could be promising predictive markers for the response to neoadjuvant therapy [49,52-54]. We found a higher pre-treatment expression of VEGFA mRNA in patients with a T-stage downstaging, indicating a higher efficiency of the neoadjuvant treatment. These results are in line with the data published by Hur and colleagues, where RC patients with high VEGFA expression levels exhibited a significantly greater pathological complete response rate [55]. These results could be explained by the increased tumor vascularization caused by the higher expression of VEGFA and, therefore, a better supply of oxygen required for the cytotoxic activities of CRT and RT [56]. However, other studies present inconsistent results where greater VEGFA expression has been found in non-responsive tumors or was unrelated to the response to preoperative RT or CRT [57,58]. Although the pre-treatment gene expression difference between the $\mathrm{T} / \mathrm{N}$-stage responders and non-responders were in the same direction as between T-stage responders 
and non-responders, the difference of VEGFA expression was not significant in this group. This could be due to a lower number of patients with T/N-stage downstaging and the analysis in a larger group of patients would be useful to draw more specific conclusions.

Analysis of VEGFA, COX2, HUR and CUGBP2 gene expression in RC tissue after neoadjuvant therapy revealed a significantly decreased expression of VEGFA, HUR and CUGBP2 mRNA, while changes in COX2 mRNA expression were not significant. Our results could be compared to the study published by Murmu et al., where the changes in COX2, CUGBP2, HUR mRNA and protein expression have been analyzed in mice small intestine mucosa after radiotherapy [28]. An increase in CUGBP2 mRNA expression in mice intestinal mucosa has been observed $6 \mathrm{~h}$ after radiotherapy and has been associated with an increased apoptosis of cancer cells and better effectiveness of the treatment. However, a decrease in the CUGBP2 gene expression and an increase in COX2 and HUR gene expression have been observed $48 \mathrm{~h}$ after radiation [28]. Similar results have been declared after evaluating changes in CUGBP2 mRNA and protein expression under radiation in RC cell cultures, where an increase in CUGBP2 expression has been observed $24 \mathrm{~h}$ after radiotherapy [29]. It might be possible that changes in CUGBP2 and HUR gene expression after radiotherapy can program further the fate of COX2 and VEGFA, for example, a fast disruption of mRNA, stabilization and the silencing of translation. Although CUGBP2 is known to stabilize COX2 mRNA and inhibit translation to protein, the increase in COX2 mRNA expression was insignificant, possibly confirming post-transcriptional gene expression regulation.

A significant decrease in VEGFA mRNA expression after neoadjuvant therapy was detected in this study. It has previously been shown that radiotherapy has the ability to inhibit tumor angiogenesis [59] and this ability might be associated with the inhibition of VEGFA expression, leading to a decreased amount of VEGFA mRNA in tissues. Moreover, a stronger downregulation of the pro-oncogenic VEGFA and COX2 mRNA following neoadjuvant therapy was observed in the group of patients with downstaged tumors (based on T-stage downstaging), while non-downstaged tumors exhibited higher VEGFA and COX2 mRNA expression. Similarly, high levels of COX2 protein expression after RT or CRT have been previously associated with low levels of tumor cell apoptosis, poor prognosis or minor histopathologic response in patients with rectal or esophageal cancer [60,61]. As we know, an increased secretion of COX2 stimulates PGE2 production and therefore increases cell proliferation. PGE2 also increases cell immunity to radiation and promotes VEGFA expression, increasing the small vascular-net formation in tumors [44,62].

It is important to mention the limitations of this study, the main one being the small amount of suitable tissue for analysis. Due to RT-induced fibrosis, a large portion of the post-treatment tissue samples was unsuitable for further analysis. Therefore, a more extensive study in a larger group of patients is needed to verify the connection between the changes in VEGFA, COX2, HUR and CUGBP2 gene expression under neoadjuvant therapy and the efficacy of the treatment.

\section{Conclusions}

In conclusion, we confirmed that VEGFA, COX2 and HUR genes are overexpressed in RC tissue and pre-treatment VEGFA expression is higher in patients with tumor T-stage downstaging, highlighting their role in RC pathogenesis and predictive potential. Our study also shows that lower VEGFA and COX2 expression levels after neoadjuvant therapy could indicate a better response to treatment.

Supplementary Materials: The following are available online at http://www.mdpi.com/1010-660X/56/4/192/s1, Table S1: A summary of patient distribution according to AJCC and TNM classification.

Author Contributions: Conceptualization, H.P. and A.T.; data curation, H.P.; investigation, methodology, formal analysis H.P. and U.G.; resources, H.P., T.L., L.K., E.B., P.L. and S.S.; writing-original draft preparation, H.P., U.G., T.L., L.K., E.B. and I.K.; visualization, U.G.; supervision, writing-review and editing, J.K. and A.T. All authors have read and agreed to the published version of the manuscript.

Funding: This research was funded by the Research Council of Lithuania under the initiative of Researcher teams' projects. Grant No: S-MIP-17-22. 
Conflicts of Interest: The authors declare no conflict of interest.

\section{References}

1. Rees, C.J.; Bevan, R.; Zimmermann-Fraedrich, K.; Rutter, M.D.; Rex, D.; Dekker, E.; Ponchon, T.; Bretthauer, M.; Regula, J.; Saunders, B.; et al. Expert opinions and scientific evidence for colonoscopy key performance indicators. Gut 2016, 65, 2045-2460. [CrossRef] [PubMed]

2. Ferlay, J.; Steliarova-Foucher, E.; Lortet-Tieulent, J.; Rosso, S.; Coebergh, J.W.W.; Comber, H.; Forman, D.; Bray, F. Cancer incidence and mortality patterns in Europe: Estimates for 40 countries in 2012. Eur. J. Cancer 2013, 49, 1374-1403. [CrossRef] [PubMed]

3. Yoon, W.H.; Kim, H.J.; Kim, C.H.; Joo, J.K.; Kim, Y.J.; Kim, H.R. Oncologic impact of pathologic response on clinical outcome after preoperative chemoradiotherapy in locally advanced rectal cancer. Ann. Surg. Treat. Res. 2015, 88, 15-20. [CrossRef]

4. Garcia-Aguilar, J.; Hernandez de Anda, E.; Sirivongs, P.; Lee, S.H.; Madoff, R.D.; Rothenberger, D.A. A pathologic complete response to preoperative chemoradiation is associated with lower local recurrence and improved survival in rectal cancer patients treated by mesorectal excision. Dis. Colon. Rectum. 2003, 46, 298-304. [CrossRef]

5. Sauer, R.; Liersch, T.; Merkel, S.; Fietkau, R.; Hohenberger, W.; Hess, C.; Becker, H.; Raab, H.-R.; Villanueva, M.-T.; Witzigmann, H.; et al. Preoperative Versus Postoperative Chemoradiotherapy for Locally Advanced Rectal Cancer: Results of the German CAO/ARO/AIO-94 Randomized Phase III Trial After a Median Follow-Up of 11 Years. J. Clin. Oncol. 2012, 30, 1926-1933. [CrossRef]

6. Bujko, K.; Nowacki, M.P.; Nasierowska-Guttmejer, A.; Michalski, W.; Bebenek, M.; Kryj, M. Long-term results of a randomized trial comparing preoperative short-course radiotherapy with preoperative conventionally fractionated chemoradiation for rectal cancer. Br. J. Surg. 2006, 93, 1215-1223. [CrossRef]

7. Bosset, J.-F.; Calais, G.; Mineur, L.; Maingon, P.; Stojanovic-Rundic, S.; Bensadoun, R.-J.; Bardet, E.; Beny, A.; Ollier, J.-C.; Bolla, M.; et al. Fluorouracil-based adjuvant chemotherapy after preoperative chemoradiotherapy in rectal cancer: Long-term results of the EORTC 22921 randomised study. Lancet Oncol. 2014, 15, 184-190. [CrossRef]

8. Gérard, J.P.; Conroy, T.; Bonnetain, F.; Bouché, O.; Chapet, O.; Closon-Dejardin, M.T.; Untereiner, M.; Leduc, B.; Francois, É; Maurel, J.; et al. Preoperative radiotherapy with or without concurrent fluorouracil and leucovorin in T3-4 rectal cancers: Results of FFCD 9203. J. Clin. Oncol. 2006, 24, 4620-4625. [CrossRef]

9. Kupcinskas, J.; Wex, T.; Bornschein, J.; Selgrad, M.; Leja, M.; Juozaityte, E.; Kiudelis, G.; Jonaitis, L.; Malfertheiner, P. Lack of association between gene polymorphisms of Angiotensin converting enzyme, Nod-like receptor 1, Toll-like receptor 4, FAS/FASL and the presence of Helicobacter pylori-induced premalignant gastric lesions and gastric cancer in Caucasians. BMC Med. Genet. 2011, 12, 112. [CrossRef]

10. Kupcinskas, J.; Gyvyte, U.; Bruzaite, I.; Leja, M.; Kupcinskaite-Noreikiene, R.; Pauzas, H.; Tamelis, A.; Jonaitis, L.; Skieceviciene, J.; Kiudelis, G. Common genetic variants of PSCA, MUC1 and PLCE1 genes are not associated with colorectal cancer. Asian Pac. J. Cancer Prev. 2015, 16, 6027-6032. [CrossRef]

11. Barontini, J.; Antinucci, M.; Tofanelli, S.; Cammalleri, M.; Dal Monte, M.; Gemignani, F.; Vodicka, P.; Marangoni, R.; Vodickova, L.; Kupcinskas, J.; et al. Association between polymorphisms of TAS2R16 and susceptibility to colorectal cancer. BMC Gastroenterol. 2017, 17, 104. [CrossRef]

12. Bogaert, J.; Prenen, H. Molecular genetics of colorectal cancer. Ann. Gastroenterol. 2014, 27, 9-14. [CrossRef]

13. Danese, E.; Montagnana, M. Epigenetics of colorectal cancer: Emerging circulating diagnostic and prognostic biomarkers. Ann. Transl. Med. 2017, 5, 279. [CrossRef] [PubMed]

14. Steponaitiene, R.; Kupcinskas, J.; Langner, C.; Balaguer, F.; Venclauskas, L.; Pauzas, H.; Tamelis, A.; Skieceviciene, J.; Kupcinskas, L.; Malfertheiner, P.; et al. Epigenetic silencing of miR-137 is a frequent event in gastric carcinogenesis. Mol. Carcinog. 2016, 55, 376-386. [CrossRef] [PubMed]

15. Link, J.; Thon, C.; Schanze, D.; Steponaitiene, R.; Kupcinskas, J.; Zenker, M.; Canbay, A.; Malfertheiner, P.; Link, A. Food-Derived Xeno-microRNAs: Influence of Diet and Detectability in Gastrointestinal Tract-Proof-of-Principle Study. Mol. Nutr. Food Res. 2019, 63, e1800076. [CrossRef] [PubMed]

16. Des Guetz, G.; Uzzan, B.; Nicolas, P.; Cucherat, M.; Morere, J.F.; Benamouzig, R.; Breau, J.L.; Perret, G.Y. Microvessel density and VEGF expression are prognostic factors in colorectal cancer. Meta-analysis of the literature. Br. J. Cancer 2006, 94, 1823-1832. [CrossRef] 
17. Yamamori, M.; Sakaeda, T.; Nakamura, T.; Okamura, N.; Tamura, T.; Aoyama, N.; Kamigaki, T.; Ohno, M.; Shirakawa, T.; Gotoh, A.; et al. Association of VEGF genotype with mRNA level in colorectal adenocarcinomas. Biochem. Biophys. Res. Commun. 2004, 325, 144-150. [CrossRef]

18. Wang, D.; Dubois, R.N. The role of COX-2 in intestinal inflammation and colorectal cancer. Oncogene 2010, 29, 781-788. [CrossRef] [PubMed]

19. Dixon, D.A.; Blanco, F.F.; Bruno, A.; Patrignani, P. Mechanistic aspects of COX-2 expression in colorectal neoplasia. Recent Results Cancer Res. 2013, 191, 7-37. [CrossRef]

20. Wu, W.K.K.; Yiu Sung, J.J.; Lee, C.W.; Yu, J.; Cho, C.H. Cyclooxygenase-2 in tumorigenesis of gastrointestinal cancers: An update on the molecular mechanisms. Cancer Lett. 2010, 295, 7-16. [CrossRef]

21. Kutchera, W.; Jones, D.A.; Matsunami, N.; Groden, J.; McIntyre, T.M.; Zimmerman, G.A.; White, R.L.; Prescott, S.M. Prostaglandin H synthase 2 is expressed abnormally in human colon cancer: Evidence for a transcriptional effect. Proc. Natl. Acad. Sci. USA 1996, 93, 4816-4820. [CrossRef]

22. Hasegawa, K.; Ichikawa, W.; Fujita, T.; Ohno, R.; Okusa, T.; Yoshinaga, K.; Sugihara, K. Expression of cyclooxygenase-2 (COX-2) mRNA in human colorectal adenomas. Eur.J. Cancer 2001, 37, 1469-1474. [CrossRef]

23. Young, L.E.; Sanduja, S.; Bemis-Standoli, K.; Pena, E.A.; Price, R.L.; Dixon, D.A. The mRNA Binding Proteins HuR and Tristetraprolin Regulate Cyclooxygenase 2 Expression During Colon Carcinogenesis. Gastroenterology 2009, 136, 1669-1679. [CrossRef] [PubMed]

24. Lim, S.-J.; Lee, S.-H.; Joo, S.H.; Song, J.Y.; Choi, S.I. Cytoplasmic Expression of HuR is Related to Cyclooxygenase-2 Expression in Colon Cancer. Cancer Res. Treat. 2009, 41, 87-92. [CrossRef]

25. Dixon, D.A.; Tolley, N.D.; King, P.H.; Nabors, L.B.; McIntyre, T.M.; Zimmerman, G.A.; Prescott, S.M. Altered expression of the mRNA stability factor HuR promotes cyclooxygenase-2 expression in colon cancer cells. J. Clin. Investig. 2001, 108, 1657-1665. [CrossRef]

26. Sureban, S.M.; Murmu, N.; Rodriguez, P.; May, R.; Maheshwari, R.; Dieckgraefe, B.K.; Houchen, C.W.; Anant, S. Functional Antagonism Between RNA Binding Proteins HuR and CUGBP2 Determines the Fate of COX-2 mRNA Translation. Gastroenterology 2007, 132, 1055-1065. [CrossRef]

27. Mukhopadhyay, D.; Jung, J.; Murmu, N.; Houchen, C.W.; Dieckgraefe, B.K.; Anant, S. CUGBP2 Plays a Critical Role in Apoptosis of Breast Cancer Cells in Response to Genotoxic Injury. Ann. N. Y. Acad. Sci. 2003, 1010, 504-509. [CrossRef] [PubMed]

28. Murmu, N.; Jung, J.; Mukhopadhyay, D.; Houchen, C.W.; Riehl, T.E.; Stenson, W.F.; Morrison, A.R.; Arumugam, T.; Dieckgraefe, B.K.; Anant, S. Dynamic antagonism between RNA-binding protein CUGBP2 and cyclooxygenase-2-mediated prostaglandin E2 in radiation damage. Proc. Natl. Acad. Sci. USA 2004, 101, 13873-13878. [CrossRef] [PubMed]

29. Ramalingam, S.; Natarajan, G.; Schafer, C.; Subramaniam, D.; May, R.; Ramachandran, I.; Queimado, L.; Houchen, C.W.; Anant, S. Novel intestinal splice variants of RNA binding protein CUGBP2: Isoform specific effects on mitotic catastrophe. Am. J. Physiol. Gastrointest. Liver Physiol. 2008, 294, G971-G981. [CrossRef] [PubMed]

30. Natarajan, G.; Ramalingam, S.; Ramachandran, I.; May, R.; Queimado, L.; Houchen, C.W.; Anant, S. CUGBP2 downregulation by prostaglandin E2 protects colon cancer cells from radiation-induced mitotic catastrophe. Am. J. Physiol. Gastrointest. Liver Physiol. 2008, 294, G1235-G1244. [CrossRef] [PubMed]

31. Hall-Pogar, T.; Zhang, H.; Tian, B.; Lutz, C.S. Alternative polyadenylation of cyclooxygenase-2. Nucleic Acids. Res. 2005, 33, 2565-2579. [CrossRef]

32. Sawaoka, H.; Dixon, D.A.; Oates, J.A.; Boutaud, O. Tristetraprolin binds to the 3'-untranslated region of cyclooxygenase-2 mRNA: A polyadenylation variant in a cancer cell line lacks the binding site. J. Biol. Chem. 2003, 278, 13928-13935. [CrossRef]

33. Tejpar, S. The multidisciplinary management of gastrointestinal cancer. The use of molecular markers in the diagnosis and treatment of colorectal cancer. Best Pract. Res. Clin. Gastroenterol. 2007, 21, 1071-1087. [CrossRef]

34. Toomey, D.P.; Murphy, J.F.; Conlon, K.C. COX-2, vegf and tumour angiogenesis. Surgeon 2009, 7, $174-180$. [CrossRef]

35. Hu, H.; Han, T.; Zhuo, M.; Wu, L.L.; Yuan, C.; Wu, L.; Lei, W.; Jiao, F.; Wang, L.W. Elevated COX-2 Expression Promotes Angiogenesis Through EGFR/p38-MAPK/Sp1-Dependent Signalling in Pancreatic Cancer. Sci. Rep. 2017, 7, 470. [CrossRef] [PubMed] 
36. Young, L.E.; Dixon, D.A. Posttranscriptional regulation of cyclooxygenase 2 expression in colorectal cancer. Curr. Colorectal. Cancer Rep. 2010, 6, 60-67. [CrossRef] [PubMed]

37. Latkauskas, T.; Pauzas, H.; Kairevice, L.; Petrauskas, A.; Saladzinskas, Z.; Janciauskiene, R.; Gudaityte, J.; Lizdenis, P.; Svagzdys, S.; Tamelis, A.; et al. Preoperative conventional chemoradiotherapy versus short-course radiotherapy with delayed surgery for rectal cancer: Results of a randomized controlled trial. BMC Cancer 2016, 16, 927. [CrossRef]

38. Latkauskas, T.; Pauzas, H.; Gineikiene, I.; Janciauskiene, R.; Juozaityte, E.; Saladzinskas, Z.; Tamelis, A.; Pavalkis, D. Initial results of a randomized controlled trial comparing clinical and pathological downstaging of rectal cancer after preoperative short-course radiotherapy or long-term chemoradiotherapy, both with delayed surgery. Colorectal Dis. 2012, 14, 294-298. [CrossRef]

39. Latkauskas, T.; Pauzas, H.; Kairevice, L.; Janciauskiene, R.; Saladzinskas, Z.; Tamelis, A.; Gineikiene, I.; Pavalkis, D. Long-term results of a randomised controlled trial comparing preoperative conventional chemoradiotherapy with short-course radiotherapy with delayed surgery for rectal cancer. Colorectal Dis. 2014, 16, 1-2. [CrossRef]

40. Claesson-Welsh, L.; Welsh, M. VEGFA and tumour angiogenesis. J. Intern. Med. 2013, 273, 114-127. [CrossRef]

41. Elzagheid, A.; Emaetig, F.; Alkikhia, L.; Buhmeida, A.; Syrjanen, K.; El-Faitori, O.; Latto, M.; Collan, Y.; Pyrhonen, S. High cyclooxygenase-2 expression is associated with advanced stages in colorectal cancer. Anticancer. Res. 2013, 33, 3137-3143. [PubMed]

42. Al-Maghrabi, J.; Buhmeida, A.; Emam, E.; Syrjänen, K.; Sibiany, A.; Al-Qahtani, M.; Al-Ahwal, M. Cyclooxygenase-2 expression as a predictor of outcome in colorectal carcinoma. World J. Gastroenterol. 2012, 18, 1793-1799. [CrossRef] [PubMed]

43. Peng, L.; Zhou, Y.; Wang, Y.; Mou, H.; Zhao, Q. Prognostic significance of COX-2 immunohistochemical expression in colorectal cancer: A meta-analysis of the literature. PLoS ONE 2013, 8, e58891. [CrossRef]

44. Nakamoto, R.H.; Uetake, H.; Iida, S.; Kolev, Y.V.; Soumaoro, L.T.; Takagi, Y.; Yasuno, M.; Sugihara, K. Correlations between cyclooxygenase-2 expression and angiogenic factors in primary tumors and liver metastases in colorectal cancer. Jpn. J. Clin. Oncol. 2007, 37, 679-685. [CrossRef]

45. Roelofs, H.M.; te Morsche, R.H.; van Heumen, B.W.; Nagengast, F.M.; Peters, W.H. Over-expression of COX-2 mRNA in colorectal cancer. BMC Gastroenterol. 2014, 14, 1. [CrossRef]

46. Cianchi, F.; Cortesini, C.; Bechi, P.; Fantappie‘, O.; Fantappie', F.; Messerini, L.; Vannacci, A.; Sardi, I.; Baroni, G.; Boddi, V.; et al. Up-regulation of Cyclooxygenase 2 Gene Expression Correlates with Tumor Angiogenesis in Human Colorectal Cancer. Gastroenterology. 2001, 121, 1339-1347. [CrossRef]

47. Luo, H.; Chen, Z.; Jin, H.; Zhuang, M.; Wang, T.; Su, C.; Lei, Y.; Zou, J.; Zhong, B. Cyclooxygenase-2 up-regulates vascular endothelial growth factor via a protein kinase $C$ pathway in non-small cell lung cancer. J. Exp. Clin. Cancer Res. 2011, 30, 6. [CrossRef]

48. Kurosu, T.; Ohga, N.; Hida, Y.; Maishi, N.; Akiyama, K.; Kakuguchi, W.; Kuroshima, T.; Kondo, M.; Akino, T.; Totsuka, Y.; et al. HuR keeps an angiogenic switch on by stabilising mRNA of VEGF and COX-2 in tumour endothelium. Br. J. Cancer 2011, 104, 819-829. [CrossRef] [PubMed]

49. Wang, J.; Guo, Y.; Chu, H.; Guan, Y.; Bi, J.; Wang, B. Multiple Functions of the RNA-Binding Protein HuR in Cancer Progression, Treatment Responses and Prognosis. Int. J. Mol. Sci. Int. J. Mol. Sci. 2013, 14, 10015-10041. [CrossRef]

50. Ramalingam, S.; Ramamoorthy, P.; Subramaniam, D.; Anant, S. Reduced Expression of RNA Binding Protein CELF2, a Putative Tumor Suppressor Gene in Colon Cancer. Immunogastroenterology 2012, 1, 27-33. [CrossRef]

51. García-Cárdenas, J.M.; Guerrero, S.; López-Cortés, A.; Armendáriz-Castillo, I.; Guevara-Ramírez, P.; Pérez-Villa, A.; Yumiceba, V.; Zambrano, A.K.; Leone, P.E.; Paz-y-Miño, C. Post-transcriptional Regulation of Colorectal Cancer: A Focus on RNA-Binding Proteins. Front. Mol. Biosci. 2019, 6, 65. [CrossRef]

52. Edden, Y.; Wexner, S.D.; Berho, M. The use of molecular markers as a method to predict the response to neoadjuvant therapy for advanced stage rectal adenocarcinoma. Colorectal Dis. 2012, 14, 555-561. [CrossRef] [PubMed]

53. Guo, H.; Ahmed, M.; Zhang, F.; Yao, C.Q.; Li, S.; Liang, Y.; Hua, J.; Soares, F.; Sun, Y.; Langstein, J.; et al. Modulation of long noncoding RNAs by risk SNPs underlying genetic predispositions to prostate cancer. Nat. Genet. 2016, 48, 1142-1150. [CrossRef] [PubMed] 
54. Okumura, H.; Uchikado, Y.; Setoyama, T.; Matsumoto, M.; Owaki, T.; Ishigami, S.; Natsugoe, S. Biomarkers for predicting the response of esophageal squamous cell carcinoma to neoadjuvant chemoradiation therapy. Surg. Today 2014, 44, 421-428. [CrossRef] [PubMed]

55. Hur, H.; Kim, N.K.; Min, B.S.; Baik, S.H.; Lee, K.Y.; Koom, W.S.; Ahn, J.B.; Kim, H. Can a biomarker-based scoring system predict pathologic complete response after preoperative chemoradiotherapy for rectal cancer? Dis. Colon. Rectum. 2014, 57, 592-601. [CrossRef]

56. Kim, N.K.; Hur, H. New perspectives on predictive biomarkers of tumor response and their clinical application in preoperative chemoradiation therapy for rectal cancer. Yonsei Med. J. 2015, 56, 1461-1477. [CrossRef]

57. Zlobec, I.; Steele, R.; Compton, C.C. VEGF as a predictive marker of rectal tumor response to preoperative radiotherapy. Cancer 2005, 104, 2517-2521. [CrossRef]

58. Qiu, H.; Sirivongs, P.; Rothenberger, M.; Rothenberger, D.A.; García-Aguilar, J. Molecular prognostic factors in rectal cancer treated by radiation and surgery. Dis. Colon. Rectum. 2000, 43, 451-459. [CrossRef]

59. Brown, J.M. Inhibiting Vasculogenesis After Radiation: A New Paradigm to Improve Local Control by Radiotherapy. Semin. Radiat. Oncol. 2013, 23, 281-287. [CrossRef]

60. De Heer, P.; Gosens, M.J.E.M.; De Bruin, E.C.; Dekker-Ensink, N.G.; Putter, H.; Marijnen, C.A.M.; Van Den Brule, A.J.C.; Van Krieken, J.H.J.M.; Rutten, H.J.T.; Kuppen, P.J.K.; et al. Cyclooxygenase 2 expression in rectal cancer is of prognostic significance in patients receiving preoperative radiotherapy. Clin. Cancer Res. 2007, 13, 2955-2960. [CrossRef]

61. Xi, H.; Baldus, S.E.; Warnecke-Eberz, U.; Brabender, J.; Neiss, S.; Metzger, R.; Ling, F.C.; Dienes, H.P.; Bollschweiler, E.; Moenig, S.; et al. High cyclooxygenase-2 expression following neoadjuvant radiochemotherapy is associated with minor histopathologic response and poor prognosis in esophageal cancer. Clin. Cancer Res. 2005, 11, 8341-8347. [CrossRef] [PubMed]

62. Ogino, S.; Kirkner, G.J.; Nosho, K.; Irahara, N.; Kure, S.; Shima, K.; Hazra, A.; Chan, A.T.; Dehari, R.; Giovannucci, E.L.; et al. Cyclooxygenase-2 expression is an independent predictor of poor prognosis in colon cancer. Clin. Cancer Res. 2008, 14, 8221-8227. [CrossRef] [PubMed] 